\title{
Heavy Metals Concentration in Teak (Tectona grandis Linn. F.) and Topsoil at Roadside in University of Benin, Benin City, Nigeria
}

\author{
*ERAKHRUMEN, AA; INAEDE, S \\ Department of Forest Resources and Wildlife Management, Faculty of Agriculture, \\ University of Benin, Benin City, Nigeria \\ "Corresponding Author Email: andrew.erakhrumen@uniben.edu; Phone: +234-(0)-803-384-0510
}

\begin{abstract}
This research was aimed at detecting some heavy metal ions in selected tissues of a standing twenty two years old Teak (Tectona grandis Linn. F.) trees and the topsoil around them at varied distance from a road within the campus of University of Benin, Benin City, Nigeria. Concentration levels of seven types of heavy metal ions were evaluated in the different samples using standard procedures. The results showed that $\mathrm{Cu}, \mathrm{Cr}, \mathrm{Zn}, \mathrm{Mn}$ and $\mathrm{Fe}$ were detected in the samples while $\mathrm{Cd}$ and $\mathrm{Pb}$ were not detected. The concentration of $\mathrm{Cu}$ was highest $(0.22 \pm 0.02 \mu \mathrm{g} / \mathrm{g})$ in leaves at a distance of $5.85 \mathrm{~m}$ from the road while it was lowest in bark $(0.09 \pm 0.01 \mu \mathrm{g} / \mathrm{g})$ and leaves $(0.09 \pm 0.01 \mu \mathrm{g} / \mathrm{g})$ at a distance of $24.10 \mathrm{~m}$ from the road. The concentration of $\mathrm{Cr}$ was found to be $0.40 \pm 0.03 \mu \mathrm{g} / \mathrm{g}$ and $0.40 \pm 0.08 \mu \mathrm{g} / \mathrm{g}$ in topsoil samples at distance of $5.85 \mathrm{~m}$ and $18.60 \mathrm{~m}$ from the road respectively but has a value of $0.17 \pm 0.002 \mu \mathrm{g} / \mathrm{g}$ in leaves at a distance of $24.10 \mathrm{~m}$ from the road. It was also observed that concentration of $\mathrm{Zn}$ was $0.93 \pm 0.06 \mu \mathrm{g} / \mathrm{g}$ in leaves at a distance of $5.85 \mathrm{~m}$ from the road but was $0.05 \pm 0.03 \mu \mathrm{g} / \mathrm{g}$ in topsoil at a distance of $24.10 \mathrm{~m}$ from the road. Additionally, the concentration of $\mathrm{Mn}$ was highest in topsoil $(1.10 \pm 0.006 \mu \mathrm{g} / \mathrm{g})$ at a distance of $18.60 \mathrm{~m}$ from the road but was lowest in bark $(0.20 \pm 0.02 \mu \mathrm{g} / \mathrm{g})$ at a distance of $24.10 \mathrm{~m}$ from the road. The concentration of Fe ions was found to be highest in topsoil samples $(89.12 \pm 0.55 \mu \mathrm{g} / \mathrm{g})$ at a distance of $5.85 \mathrm{~m}$ from the road but was lowest in bark $(2.07 \pm 0.07 \mu \mathrm{g} / \mathrm{g})$ at a distance of $24.10 \mathrm{~m}$ from the road. The results revealed a somewhat common trend where concentrations of all the detected heavy metal ions declined in the samples of topsoil and teak's tissues as the distance of the locations where the samples were sourced increased from the roadside. The outcomes of this research appeared to have implicated automobiles as the main source of these pollutants; nevertheless, more intensive scientific investigations are necessary to provide answers to existing questions concerning ascertaining the source(s) of these pollutants, if not from petroleum fuelled automobiles, and the possible roles and ability of this tree species, or otherwise, in contributing to environmental cleaning in the study area.
\end{abstract}

\section{DOI: https://dx.doi.org/10.4314/jasem.v22i10.18}

Copyright: Copyright $(0) 2018$ Erakhrumen and Inaede. This is an open access article distributed under the Creative Commons Attribution License (CCL), which permits unrestricted use, distribution, and reproduction in any medium, provided the original work is properly cited.

Dates: Received: 10 September 2018; Revised: 12 October 2018; Accepted: 29 October 2018

Keywords: Toxic/noxious substances, Soil pollution, Heavy metal contamination, Phytoremediation

The environment in which an organism finds itself or gets itself into is an important factor influencing not only its health condition but also its level of survival and longevity. These are some of the reasons why there are increasing interests in identifying the types and sources of substances that contribute to environmental degradation and how this challenge can be surmounted in the present and future. It is a documented fact that environmental degradation has been largely traced to anthropogenic activities, one of which is the generation of noxious/toxic substances. Thus, solutions should be proffered taking into cognisance these anthropogenic activities. Irrespective of this suggestion, the certainty is that there are already some noxious/toxic substances in the environment including those that cannot be stopped from being generated, that must be removed from, or detoxified within, the environment (air, water, soil, etc.) using reliable and sustainable strategies. Firstly, there is the need to ascertain the presence and identity of noxious/toxic substances of interest in the environment through proper sampling and scientific analyses. This is in order to determine ways they could be dealt with so that possible means regarding how their negative impacts could be drastically reduced are arrived at. Apart from sampling air, water, soil, or other suspected polluted milieu for laboratory investigations, some living organisms are also known to give clues that signify possible pollution of their environment by certain substance(s). This phenomenon/function is simply referred to as bioindication (Erakhrumen, 2014). Some plants, among these organisms, possess the ability to allow high concentrations of noxious/toxic substances in their tissues and/or participate in controlling them in the environment through processes collectively known as phytoremediation (Erakhrumen, 2007; Erakhrumen, 2015; Erakhrumen and Akhigbe, 2016). Apart from the earlier stated benefits derivable from different types of plants, there are others, such as the production 
of harvestable resources and participation of some plants in environmental stabilisation. These functions are part of the reasons why plant biomass, for example trees in urban settings, is being increasingly recommended for establishment. Consequently, urban forestry has attracted increased global awareness and acceptance. Urban forestry is a practical discipline, merely defined as the art, science and technology of managing trees and forest resources in and around urban community ecosystems for the physiological, sociological, economic, and aesthetic benefits trees provide society (Konijnendijk et al., 2006). Among this kind of trees are those planted on distinct plots of single or multiple species or those serving as avenue trees for multifaceted purposes. Urban forestry is not really a new concept, although, it is one which still appears to have growing potential in developing countries. These developing countries are where urbanisation is increasing at a rapid rate and a demographic switch from a predominantly rural to a predominantly urban society is taking place (Carter, 1994). As laudable as tree planting may be within urban settings, there are some arboricultural challenges posed by urban environment to trees, most especially those sited close to roads. Examples of these challenges are those linked to physical, mechanical and chemical damage to trees and stresses they undergo from automobile exhaust (Pickett et al., 2001). These and other constraint the typical urban environment places on trees planted within it limits the average lifespan of an urban tree (Herwitz, 2001). There is therefore the need for continuous monitoring of these conditions in order to be able to develop proper dynamic management strategies for these trees. In line with the foregoing, this research was carried out to assess presence and concentrations of selected heavy metals in some tissues of standing 22 years old Tectona grandis trees and their surrounding topsoil. This stand is currently located on a plot partly bordered by a road used by pedestrians and motorists within the campus of University of Benin, Benin City, Nigeria.

\section{MATERIALS AND METHODS}

Samples collection site: Test samples for this research were obtained from a stand of Tectona grandis Linn. F. established in 1996 within the University of Benin, Benin City, on the southern part of Edo State, Nigeria. This southern part of Edo State has a topography that is flat with gentle slope. The area has an annual rainfall of between 1,500 and $2,000 \mathrm{~mm}$ with an average temperature of $25^{\circ} \mathrm{C}$ in the rainy season and $28^{\circ} \mathrm{C}$ in the dry season. It is part of a low lying plain covered with porous sand that rises gently north-eastward, with soils derived from sand stones and shades and very recent deposits susceptible to leaching (Egbe et al., 1989; Kalu and Anigbere, 2011). Using a geographical positioning system devise, this teak stand was found to be located on latitude $06^{\circ} 24^{\prime} 14^{\prime \prime} \mathrm{N}$ and longitude $05^{\circ} 37^{\prime} 38^{\prime \prime} \mathrm{E}$.

Sampling procedure: (a) Bark from the sampled teak trees were obtained from the stem at a height of $1.3 \mathrm{~m}$ above ground level. This was done for the trees at three locations differentiated by their distance from the road. The distance of the first group of trees from the road was $5.85 \mathrm{~m}$ while the second group was at a distance of $18.60 \mathrm{~m}$ away from the road with the third group being located at $24.10 \mathrm{~m}$ away from the road. The bark samples were carefully rinsed with distilled water and placed in sealed properly labelled, chemically clean, polythene bags with samples from the different trees placed in differently sealed polythene bags ensuring their protection from external contamination and taken to the laboratory for subsequent analyses of presence and bioconcentrations of the selected heavy metals.

(b) Leaves were also obtained from the same trees from which bark tissues were sampled. The sampled leaves were rinsed with distilled water and also placed in another set of properly labelled, chemically clean, polythene bags that were sealed and transferred immediately to the laboratory for subsequent analyses of presence and bio-concentrations of the selected heavy metals.

(c) Topsoil samples were obtained close to each of the trees from which bark and leaves were obtained at a depth of $5 \mathrm{~cm}$ in such a way that introduction of plant matter was avoided. Samples weighing $0.5 \mathrm{~kg}$ each were collected close to each group of trees at the different distance from the road, using a clean stainless steel scoop and kept differently in properly labelled polypropylene containers that were carefully sealed to avoid contamination. They were transferred to the laboratory, in ice boxes, and stored at a temperature of $4^{\circ} \mathrm{C}$ to prevent microbial activity.

Samples of bark and leaves: The samples of bark and leaves obtained from the different trees were carefully oven-dried at $80 \pm 5^{\circ} \mathrm{C}$ in the laboratory to constant weight, broken down separately into pieces, pulverised to fine powder, in an even mix, using a laboratory mortar and pestle, making sure external contaminations were carefully avoided and subsequently kept separately in desiccators. The pulverised samples were sieved to assist in dissolution since the samples were prepared to be analysed in solution form. The wet digestion method was adopted to extract heavy metals from the samples of bark and leaves in accordance with methods described by AOAC, (1984). One (1) gramme of each pulverised and sieved sample from the different tissues (bark and 
leaves) were measured into a different chemically clean beaker. A $30 \mathrm{ml}$ volume of concentrated $\mathrm{HNO}_{3}$ was added to each of the replicates and heated at $80^{\circ} \mathrm{C}$ until total dissolution was attained. The digested samples were allowed to cool and then filtered through $0.45 \mu \mathrm{m}$ pore size Whatman filter paper, made up to fill a standard $100 \mathrm{ml}$ volumetric flask with deionised water, then stored in well labelled, chemically clean, plastic reagent bottles and analysed for presence and bio-concentrations of heavy metals using a Buck Scientific 210 VGP flame atomic absorption spectrophotometer (AAS).

Soil samples: The soil samples were first dried in an electric oven at a temperature of $35 \pm 2^{\circ} \mathrm{C}$ until the weight became constant. The samples were homogenised after being crushed and sieved using stainless steel sieves of size $\leq 2 \mathrm{~mm}$ mesh. The extractions were performed on fractions of size $\leq 2 \mathrm{~mm}$ to ensure homogeneity of the samples. The larger soil particles were completely removed. Sequential metals extraction method was adopted in accordance with methods described by AOAC, (1984). One (1) gramme each of the different soil samples was measured into different chemically clean beaker and $20 \mathrm{ml}$ volume of concentrated $\mathrm{HNO}_{3}$ and $\mathrm{HCl}$ were added, in ratio $1: 1$, to each of the replicates and heated at $80^{\circ} \mathrm{C}$ until a clear solution was obtained. While the acid was drying out, $10 \mathrm{ml} \mathrm{HCl}$ was added twice. The digested samples were also allowed to cool, filtered through $0.45 \mu \mathrm{m}$ pore size Whatman filter paper, made up to fill a standard $100 \mathrm{ml}$ volumetric flask with deionised water, then stored in labelled chemically clean plastic reagent bottles and analysed for presence and concentrations of heavy metals using a Buck Scientific 210 VGP flame AAS.

Statistical analyses: The data obtained for heavy metals' bio-concentrations in the bark and leaves of the trees and concentrations of heavy metals obtained for topsoil samples were statistically described using basic tools such as mean and standard deviation. In addition, analyses of variance (ANOVA) was employed in analysing data for statistical significant variation $(\mathrm{p} \leq 0.05)$ while Fishers' Least Significant Difference (LSD) was applied for separation of significantly different means $(\mathrm{p} \leq 0.05)$.

\section{RESULTS AND DISCUSSION}

It was observed that the mean concentrations of copper ions significantly reduced in value from $0.12 \pm 0.02 \mu \mathrm{g} / \mathrm{g}$ in bark samples obtained from teak trees located $5.85 \mathrm{~m}$ away from the road to $0.09 \pm 0.01 \mu \mathrm{g} / \mathrm{g}$ in bark samples obtained from teak trees located $24.10 \mathrm{~m}$ away from the road. Similar trend was observed for samples of leaves $(0.22 \pm 0.02$ to $0.09 \pm 0.01 \mu \mathrm{g} / \mathrm{g})$ and topsoil $(0.16 \pm 0.02$ to $0.13 \pm 0.02 \mu \mathrm{g} / \mathrm{g}$ ) at these two locations, i.e. $5.85 \mathrm{~m}$ and $24.10 \mathrm{~m}$ away from the road respectively. The outcomes of separation of means for concentrations of copper ions detected in the samples of bark, leaves and topsoil at $5.85 \mathrm{~m}$ and $18.60 \mathrm{~m}$ away from the road showed that there was significant difference, among the different samples evaluated, within each of the two locations. Nonetheless, there was no significant difference in the mean values obtained for concentrations of copper ions detected in samples of bark and leaves at $24.10 \mathrm{~m}$ away from the road (Table 1). Mean concentration values for chromium ions reduced significantly from $0.28 \pm 0.01$ to $0.22 \pm 0.01 \mu \mathrm{g} / \mathrm{g}$ for bark obtained from teak trees at $5.85 \mathrm{~m}$ and $24.10 \mathrm{~m}$ away from the road respectively. Mean concentrations for chromium ions significantly reduced from $0.34 \pm 0.02 \mu \mathrm{g} / \mathrm{g}$ for leaves obtained from teak trees located $5.85 \mathrm{~m}$ away from the road to $0.17 \pm 0.02 \mu \mathrm{g} / \mathrm{g}$ in leaves obtained from teak trees located $24.10 \mathrm{~m}$ away from the road. Mean concentrations for chromium ions significantly reduced from $0.40 \pm 0.03$ to $0.30 \pm 0.03 \mu \mathrm{g} / \mathrm{g}$ in topsoil around teak trees located $5.85 \mathrm{~m}$ and $24.10 \mathrm{~m}$ away from the road respectively. There was significant difference in the mean values obtained for concentrations of chromium ions in samples of bark, leaves and topsoil at each of all the distance from the road (Table 2). Also, mean concentration values for zinc ions significantly reduced from $0.41 \pm 0.03$ to $0.28 \pm 0.02 \mu \mathrm{g} / \mathrm{g}$ in bark obtained from teak trees located $5.85 \mathrm{~m}$ and $24.10 \mathrm{~m}$ away from the road respectively. Similarly, mean concentrations of zinc ions also significantly reduced from $0.93 \pm 0.06 \mu \mathrm{g} / \mathrm{g}$ in leaves sourced from teak trees located $5.85 \mathrm{~m}$ away from the road to $0.09 \pm 0.01 \mu \mathrm{g} / \mathrm{g}$ in leaves sourced from teak trees located $24.10 \mathrm{~m}$ away from the road (Table 3 ).

Table 1: Concentrations of copper ions in the selected tissues of some standing $T$. grandis trees and their surrounding topsoil in the three different locations from the road

\begin{tabular}{lccc}
\hline & \multicolumn{3}{c}{ Concentrations of Cu ions $(\boldsymbol{\mu g} / \mathrm{g})$} \\
\cline { 2 - 4 } & $\begin{array}{c}\mathbf{5 . 8 5 m} \text { from } \\
\text { the road }\end{array}$ & $\begin{array}{c}\mathbf{1 8 . 6 0 m} \text { from } \\
\text { the road }\end{array}$ & $\begin{array}{c}\mathbf{2 4 . 1 0 m} \text { from } \\
\text { the road }\end{array}$ \\
Bark & $0.12^{\mathrm{a}} \pm 0.02$ & $0.10^{\mathrm{a}} \pm 0.01$ & $0.09^{\mathrm{a}} \pm 0.01$ \\
Leaves & $0.22^{\mathrm{b}} \pm 0.02$ & $0.20^{\mathrm{b}} \pm 0.006$ & $0.09^{\mathrm{a}} \pm 0.01$ \\
Topsoil & $0.16^{\mathrm{c}} \pm 0.02$ & $0.14^{\mathrm{c}} \pm 0.02$ & $0.13^{\mathrm{b}} \pm 0.02$ \\
\hline
\end{tabular}

Means with the same superscript in the same column are not significantly different $(\mathrm{p}<0.05)$

Table 2: Concentrations of chromium ions in the selected tissues of some standing $T$. grandis trees and their surrounding topsoil in the three different locations from the road

\begin{tabular}{llll}
\hline & \multicolumn{3}{c}{ Concentrations of Cr ions $(\boldsymbol{\mu g} / \mathrm{g})$} \\
\cline { 2 - 4 } & $\begin{array}{l}\mathbf{5 . 8 5 m} \text { from } \\
\text { the road }\end{array}$ & $\begin{array}{l}\mathbf{1 8 . 6 0 m} \text { from } \\
\text { the road }\end{array}$ & $\begin{array}{l}\mathbf{2 4 . 1 0 m} \\
\text { from the } \\
\text { road }\end{array}$ \\
Bark & $0.28^{\mathrm{a}} \pm 0.01$ & $0.25^{\mathrm{a}} \pm 0.01$ & $0.22^{\mathrm{a}} \pm 0.01$ \\
Leaves & $0.34^{\mathrm{b}} \pm 0.02$ & $0.21^{\mathrm{b}} \pm 0.006$ & $0.17^{\mathrm{b}} \pm 0.002$ \\
Topsoil & $0.40^{\mathrm{c}} \pm 0.03$ & $0.40^{\mathrm{c}} \pm 0.08$ & $0.30^{\mathrm{c}} \pm 0.03$ \\
\hline
\end{tabular}


Means with the same superscript in the same column are not significantly different $(\mathrm{p} \leq 0.05)$

Table 3: Concentrations of zinc ions in the selected tissues of some standing $T$. grandis trees and their surrounding topsoil in the three different locations from the road

\begin{tabular}{lccc}
\hline & \multicolumn{3}{c}{ Concentrations of $\mathbf{Z n}$ ions $(\boldsymbol{\mu g} / \mathbf{g})$} \\
\cline { 2 - 4 } & $\begin{array}{c}\mathbf{5 . 8 5 m} \text { from } \\
\text { the road }\end{array}$ & $\begin{array}{c}\mathbf{1 8 . 6 0 m} \text { from } \\
\text { the road }\end{array}$ & $\begin{array}{c}\mathbf{2 4 . 1 0 m} \text { from } \\
\text { the road }\end{array}$ \\
Bark & $0.41^{\mathrm{a}} \pm 0.03$ & $0.29^{\mathrm{a}} \pm 0.06$ & $0.28^{\mathrm{a}} \pm 0.02$ \\
Leaves & $0.93^{\mathrm{b}} \pm 0.06$ & $0.37^{\mathrm{b}} \pm 0.04$ & $0.09^{\mathrm{b}} \pm 0.01$ \\
Topsoil & $0.17^{\mathrm{c}} \pm 0.005$ & $0.06^{\mathrm{c}} \pm 0.03$ & $0.05^{\mathrm{c}} \pm 0.03$ \\
\hline Means with the same superscript in the same column are not \\
significantly different $(\mathrm{p} \leq 0.05)$
\end{tabular}

As observed for copper and chromium ions, concentrations for zinc also significantly reduced in values from $0.17 \pm 0.005 \mu \mathrm{g} / \mathrm{g}$ in topsoil samples obtained around teak trees located $5.85 \mathrm{~m}$ away from the road to $0.05 \pm 0.003 \mu \mathrm{g} / \mathrm{g}$ in topsoil samples obtained around teak trees located $24.10 \mathrm{~m}$ away from the road. Statistical significant difference was observed in mean values for concentrations of zinc ions detected in samples of bark, leaves and topsoil at each of all the distance from the road (Table 3). It was observed that the concentration values of manganese ions where significantly reduced from $0.40 \pm 0.02 \mu \mathrm{g} / \mathrm{g}$ in bark from teak trees located $5.85 \mathrm{~m}$ away from the road to $0.20 \pm 0.02 \mu \mathrm{g} / \mathrm{g}$ in bark from teak trees located $24.10 \mathrm{~m}$ away from the road. The concentrations of manganese ions also significantly declined from $0.40 \pm 0.02$ to $0.28 \pm 0.02 \mu \mathrm{g} / \mathrm{g}$ in leaves obtained from teak trees located $5.85 \mathrm{~m}$ and $24.10 \mathrm{~m}$ away from the road respectively. Mean concentrations of manganese ions increased slightly from $0.96 \pm 0.01 \mu \mathrm{g} / \mathrm{g}$ in topsoil samples obtained around teak trees located $5.85 \mathrm{~m}$ away from the road to $1.10 \pm 0.006 \mu \mathrm{g} / \mathrm{g}$ in topsoil samples obtained around teak trees located $18.60 \mathrm{~m}$ away from the road but declined to $0.89 \pm 0.02 \mu \mathrm{g} / \mathrm{g}$ in topsoil samples obtained around teak trees located $24.10 \mathrm{~m}$ away from the road. There was no significant difference in the mean values obtained for concentrations of manganese ions detected in bark and leaves sourced from trees located $5.85 \mathrm{~m}$ away from the road. However, significant difference was observed in mean values of concentrations of manganese ions in bark, leaves and topsoil at each of the other distance from the road (Table 4). Mean concentration values of iron ions also followed the earlier trend. It declined significantly from $4.27 \pm 0.03 \mu \mathrm{g} / \mathrm{g}$ in bark obtained from teak trees located $5.85 \mathrm{~m}$ away from the road to $2.07 \pm 0.07 \mu \mathrm{g} / \mathrm{g}$ in bark from teak trees located $24.10 \mathrm{~m}$ away from the road. It was observed that mean concentrations of iron ions significantly declined from $7.80 \pm 0.03 \mu \mathrm{g} / \mathrm{g}$ in leaves obtained from teak trees located $5.85 \mathrm{~m}$ away from the road to $2.70 \pm 0.02 \mu \mathrm{g} / \mathrm{g}$ in leaves obtained from teak trees located $24.10 \mathrm{~m}$ away from the road. Similar trend was also obtained for topsoil where concentrations of iron ions reduced significantly from $89.12 \pm 0.55 \mu \mathrm{g} / \mathrm{g}$ for samples sourced around teak trees located $5.85 \mathrm{~m}$ away from the road to $49.92 \pm 0.03 \mu \mathrm{g} / \mathrm{g}$ for those sourced around teak trees located $24.10 \mathrm{~m}$ away from the road. There was significant difference in the mean values obtained for concentration of iron ions in samples of bark, leaves and topsoil at each of all the distance from the road (Table 5). Results for the detected ions of chromium, manganese and iron revealed that samples of topsoil, at each of the distance from the road, had higher concentrations in comparison with those for bark and leaves from teak trees (Tables 2, 4 and 5) while this was not completely so for detected copper and zinc ions (Table 1 and 3 ). It is also noteworthy that concentrations of iron ions were comparatively higher than the other detected heavy metal ions in the samples of topsoil and teak's bark and leaves at all the distance away from the road.

This research outcomes in which the concentrations of all the detected heavy metals in samples of topsoil close to the road were higher than those for topsoil at increasing distance from the road appeared to be in line with those for some similar studies, such as Voegborlo and Chirgawi (2007); Bai et al., (2008), Nakayama et al., (2011) and Aslam et al., (2013), where similar observations of this kind, concerning heavy metals, were linked to levels of traffic density and distance of topsoil from roads regularly used by motorised vehicles powered by petroleum fuels. The main medium through which these pollutants are released from these vehicles, according to studies, is their exhaust gases after the combustion of the different types of fuels by the different vehicles. The constituents of these exhaust gases, most importantly the noxious/toxic ones, are not only deposited on nearby topsoil and plants but are also dispersed by wind away from the source. They can be dispersed as far as between $100 \mathrm{~m}$ and $200 \mathrm{~m}$ from roadside (Trombulak and Frissel, 2000; Dan-Badjo et al., 2008). These heavy metal ions are also released during other operations of road transport such as through component wear, fluid leakage, corrosion of batteries and metallic parts such as radiators, wearing out of tyres, leakage of oils, among others (Akbar et al., 2006; Dolan et al., 2006; Baker et al., 2007; Ikenaka et al., 2010). Reported studies are available that have noted that plants growing on soils contaminated with these heavy metal ions including animals living within the contaminated area most likely end up having these ions in their tissues through different means in variable concentrations (Grue et al., 1986; Beslaneev and Kuchmazokova, 1991; Ara et al., 1996; Iqbal and Shazia, 2004) with those plants growing in close proximity to roads used regularly by petroleum fuelled 
motorised vehicles having higher concentrations when compared with same plant species growing at increasing distance from these same roads (Maher et al., 2008; Lacatusu et al., 2009; Ikenaka et al., 2010). In addition to this observation, that plants growing close to these roads were being contaminated with heavy metals from vehicles, it was noted that some of these plants, as a result of their exposure to these contaminants and their possession of certain ability, contribute to environmental cleaning. Studies have shown that these plants, particularly trees, play vital roles in controlling heavy metal pollution in an area and in the soil of tree planted areas through mechanisms collectively described as phytoremediation (Zhang, 2012; Liu et al., 2015; Dizaji et al., 2016). Phytoremediation is likely to be one of the functions performed by the teak trees from which tissues were obtained for experimentations in this research, especially when considering the observed decline in concentrations of heavy metals in their tissues as distance of tree location increased from the road, although, more comprehensive studies, specifically aimed at this, are necessary to ascertain if this is a possibility for this tree species growing in this study area and other similar locations. The outcomes of this study, as earlier stated, indicate that the most likely sources of the detected heavy metals in evaluated topsoil and plant tissues are the activities associated with vehicular movements on adjoining $\operatorname{road}(s)$ to where samples of the topsoil and plant tissues were obtained. Nevertheless, there is the possibility for other sources of these contaminants. For instance, other anthropogenic activities like application of fertilizers to soil, industrial and energy production activities, construction, sludge and waste disposal, among others, can also contribute significantly to heavy metal pollution of soil and associated biota (Li et al., 2001; Turer and Maynard, 2003). Some roadside activities that may also contribute to this kind of pollution in developing countries like Nigeria are vehicle and auto-electrical repairs, vulcanizing, welding, battery charging and dealing in other motor transportation facilities, among others (Mabogunje, 1980) although, these activities were in no way observed to be present at this part of the university campus during collection of samples. Furthermore, some other heavy metal ions that were tested for, such as cadmium and lead, were not detected in all the samples (Table 6 and 7). These heavy metals, particularly lead, have been reported in publications to be almost always present in topsoil and tissues of plants polluted by exhaust from automobiles after fuel combustion in vehicular engines (Gratani et al., 1992; Bahemuka and Mubofu, 1999; Renberg et al., 2000; Yaman et al., 2000; Andrews and Sutherland, 2004; Finster et al., 2004; Yakupoglu et al., 2008; Ikenaka et al., 2010; Aslam et al., 2013). Certain chemical compounds, known to contain lead, were added to gasoline in the past and currently in parts of the world as anti-knocking agent (Wheeler and Rolfe, 1979; Hafen and Brinkmann, 1996; Turer and Maynard, 2003; Iqbal and Shazia, 2004) although, efforts are increasing towards ensuring the reduction in the maximum permitted quantity of lead in fuels (Voegborlo and Chirgawi, 2007). For instance, it was reported that lead content in gasoline was markedly decreased in the United Kingdom after the introduction of the regulations requiring the reduction in the lead content from $0.64 \mathrm{~g} / \mathrm{l}$ in 1966 to $0.14 \mathrm{~g} / \mathrm{l}$ in 1986 . This reported decrease in the quantity of chemical compounds containing lead as an inclusion in some petroleum fuel has been noted to have contributed to the reduction in the addition of this heavy metal to the environment by motor vehicles in that part of the world (Akbar et al., 2006). The foregoing is noteworthy because substantial proportion of the total volume of the refined petroleum products consumed through vehicular and other usage in Nigeria is currently imported from overseas. Therefore, the likely implication of non-detection of lead in all the evaluated samples might be that the levels of lead in the combusted fuels was so low that its ions released with the vehicular exhausts were below detection level or that the fuels predominantly combusted by vehicles in the study area were unleaded or that the detected heavy metal ions were probably not from vehicular exhausts. These statements may currently appear speculative owing to the fact that the experiments to ascertain them were beyond the scope of this study; however, future studies are necessary to fill these research gaps identified through this study.

Table 4: Concentrations of manganese ions in the selected tissues of some standing $T$. grandis trees and their surrounding topsoil in the three different locations from the road

\begin{tabular}{lccc}
\hline & \multicolumn{3}{c}{ Concentrations of Mn ions $(\boldsymbol{\mu g} / \mathbf{g})$} \\
\cline { 2 - 4 } & $\begin{array}{c}\mathbf{5 . 8 5 m} \text { from } \\
\text { the road }\end{array}$ & $\begin{array}{c}\mathbf{1 8 . 6 0 m} \text { from } \\
\text { the road }\end{array}$ & $\begin{array}{c}\mathbf{2 4 . 1 0 m} \text { from } \\
\text { the road }\end{array}$ \\
Bark & $0.40^{\mathrm{a}} \pm 0.02$ & $0.21^{\mathrm{a}} \pm 0.02$ & $0.20^{\mathrm{a}} \pm 0.02$ \\
Leaves & $0.40^{\mathrm{a}} \pm 0.02$ & $0.29^{\mathrm{b}} \pm 0.002$ & $0.28^{\mathrm{b}} \pm 0.02$ \\
Topsoil & $0.96^{\mathrm{b}} \pm 0.01$ & $1.10^{\mathrm{c}} \pm 0.006$ & $0.89^{\mathrm{c}} \pm 0.02$ \\
\hline
\end{tabular}

Means with the same superscript in the same column are not significantly different $(\mathrm{p} \leq 0.05)$

Table 5: Concentrations of iron ions in the selected tissues of some standing $T$. grandis trees and their surrounding topsoil in the three different locations from the road

\begin{tabular}{lccc}
\hline & \multicolumn{3}{c}{ Concentrations of Fe ions $(\boldsymbol{\mu g} / \mathbf{g})$} \\
\cline { 2 - 4 } & $\begin{array}{c}\mathbf{5 . 8 5 m} \text { from } \\
\text { the road }\end{array}$ & $\begin{array}{c}\mathbf{1 8 . 6 0 m} \text { from } \\
\text { the road }\end{array}$ & $\begin{array}{c}\mathbf{2 4 . 1 0 m} \text { from } \\
\text { the road }\end{array}$ \\
Bark & $4.27^{\mathrm{a}} \pm 0.03$ & $4.19^{\mathrm{a}} \pm 0.2$ & $2.07^{\mathrm{a}} \pm 0.07$ \\
Leaves & $7.80^{\mathrm{b}} \pm 0.03$ & $3.49^{\mathrm{b}} \pm 0.02$ & $2.70^{\mathrm{b}} \pm 0.02$ \\
Topsoil & $89.12^{\mathrm{c}} \pm 0.55$ & $53.99^{\mathrm{c}} \pm 0.57$ & $49.92^{\mathrm{c}} \pm 0.03$ \\
\hline
\end{tabular}

Means with the same superscript in the same column are not significantly different $(\mathrm{p} \leq 0.05)$ 
Table 6: Concentrations of cadmium ions in the selected tissues of some standing $T$. grandis trees and their surrounding topsoil in the three different locations from the road

\begin{tabular}{lccc}
\hline & \multicolumn{3}{c}{ Concentrations of Cd ions $(\boldsymbol{\mu g} / \mathbf{g})$} \\
\cline { 2 - 4 } & $\begin{array}{c}\mathbf{5 . 8 5 m} \text { from } \\
\text { the road }\end{array}$ & $\begin{array}{c}\mathbf{1 8 . 6 0 m} \text { from } \\
\text { the road }\end{array}$ & $\begin{array}{c}\mathbf{2 4 . 1 0 m} \text { from the } \\
\text { road }\end{array}$ \\
Bark & Not detected & Not detected & Not detected \\
Leaves & Not detected & Not detected & Not detected \\
Topsoil & Not detected & Not detected & Not detected \\
\hline Note: Cadmium ions may be below detection level in samples
\end{tabular}

Table 7: Concentrations of lead ions in the selected tissues of some standing $T$. grandis trees and their surrounding topsoil in the three different locations from the road

\begin{tabular}{|c|c|c|c|}
\hline \multirow{5}{*}{$\begin{array}{l}\text { Bark } \\
\text { Leaves } \\
\text { Topsoil }\end{array}$} & \multicolumn{3}{|c|}{ Concentrations of $\mathrm{Pb}$ ions $(\mu \mathrm{g} / \mathrm{g})$} \\
\hline & $\begin{array}{c}5.85 \mathrm{~m} \text { from } \\
\text { the road }\end{array}$ & $\begin{array}{c}18.60 \mathrm{~m} \text { from } \\
\text { the road }\end{array}$ & $\begin{array}{c}24.10 \mathrm{~m} \text { from } \\
\text { the road }\end{array}$ \\
\hline & Not detected & Not detected & Not detected \\
\hline & Not detected & Not detected & Not detected \\
\hline & Not detected & Not detected & Not detected \\
\hline
\end{tabular}

Conclusion: It is easy to conclude, based on the outcomes of this research, that the source of the different heavy metals detected in plant tissues form standing Tectona grandis trees and the surrounding topsoil in this study area was vehicular emissions. However, several other factors may be at play that might require more intensive investigations. While not assuming that this tree species is involved in dendroremediation or foreclosing this possibility in this study area, it would also be necessary to include this type of research in the more intensive scientific investigations earlier suggested.

\section{REFERENCES}

Akbar, KF; Hale, WHG; Headley, AD; Athar, M (2006). Heavy Metal Contamination of Roadside Soils of Northern England. Soil and Water Research, 1(4): 158-163.

Andrews, S; Sutherland, RA (2004). Cu, Pb and $\mathrm{Zn}$ Contamination in Nuuanu Watershed, Oahu, Hawaii. Science of the Total Environment, 324: 173-182.

AOAC, (1984). Official Methods of Analysis. 14th Edition by Association of Official Analytical Chemist (AOAC), Arlington, Virginia, USA.

Ara, F; Iqbal, MZ; Qureshi, MS (1996). Determination of Heavy Metals Contamination of Trees and Soils due to Vehicular Emission in Karachi City. Karachi University Journal of Science, 24: 80-84.

Aslam, J; Khan, SA; Khan, SH (2013). Heavy Metals Contamination in Roadside Soil near Different Traffic Signals in Dubai, United Arab Emirates. Journal of Saudi Chemical Society, 17: 315-319.
Bahemuka, TE; Mubofu, EB (1999). Heavy Metals in Edible Green Vegetables Grown along the Sites of the Sinza and Msimbazi Rivers in Dar es Salaam, Tanzania. Food Chemistry, 66: 63-66.

Bai, J; Cui, B; Wang, Q; Gao, H; Ding, Q (2008). Assessment of Heavy Metal Contamination of Roadside Soils in Southwest China. Stochastic Environmental Research and Risk Assessment, 23(3): 341-347.

Baker, JM; Ochsner, TE; Venterea, RT; Griffis, TJ (2007). Tillage and Soil Carbon Sequestration What Do We Really Know? Agriculture, Ecosystems and Environment, 118: 1-5.

Beslaneev, VD; Kuchmazokova, FA (1991). The Effect of Motor-Ways on the Accumulation of Toxic Substances in Walnuts. Sadovodstvo $i$ Vinogradarstvo, 5: 38.

Carter, EJ (1994). The Potential of Urban Forestry in Developing Countries: A Concept Paper. Published by the Food and Agriculture Organization (FAO) of the United Nations, Rome, Italy. Available at: http://www.fao.org/docrep/005/t1680e/T1680E0 0.htm\#TOC

Dan-Badjo, AT; Rychen, G; Docoulombier, C (2008). Pollution Maps of Grass Contamination by Platinum Group Elements and Polycyclic Aromatic Hydrocarbon from Road Traffic. Agronomy for Sustainable Development, 28(4): 457-467.

Dizaji, EF; Kafi, M; Khalighi, A; Jari, SK (2016). Phytoremediation of Lead and Cadmium by Thornless Honey Loccust Trees' (Gleditsia triacanthos L. var. inermis) in Contaminated Soil near the Tehran-Karaj Highway. Indian Journal of Agricultural Research, 50(6): 579-583.

Dolan, MS; Clapp, CE; Allmaras, RR; Baker, JM; Molina, JAE (2006). Soil Organic Carbon and Nitrogen in a Minnesota Soil as Related to Tillage, Residue and Nitrogen Management. Soil and Tillage Research, 89(2): 221-231.

Egbe, NE; Ayodele, EA; Obatotu, CR (1989). Soil Nutrition of Cocoa, Kola, Cashew and Trees: Progress in Tree Crop Research (2nd Edition): Ibadan, Nigeria. Pp. 28-30. 
Erakhrumen, AA (2007). Phytoremediation: An Environmentally Sound Technology for Pollution Prevention, Control and Remediation in Developing Countries. Educational Research and Review, 2(7): 151-156.

Erakhrumen, AA (2014). Potentials of Rhizophora racemosa for Bio-Indication and Dendroremediation of Heavy Metal Contamination in a Mangrove Forest, Ondo State, Nigeria. Nigerian Journal of Agriculture, Food and Environment, 10(4): 1-5.

Erakhrumen, AA (2015). Assessment of In-Situ Natural Dendroremediation Capability of Rhizophora racemosa in a Heavy Metal Polluted Mangrove Forest, Rivers State, Nigeria. Journal of Applied Sciences \& Environmental Management, 19(1): 21-27.

Erakhrumen, AA; Akhigbe, OG (2016). Heavy Metal Examination of Selected Tissues from Three Rhizophora Species, Adjoining Soil and Water in a Mangrove Forest, Delta State, Nigeria. Nigerian Journal of Tropical Agriculture, 16: 102-110.

Finster, ME; Gray, KA; Binns, HJ (2004). Lead Levels of Edibles Grown in Contaminated Residential Soils: A Field Survey. Science of the Total Environment, 320(2-3): 245-257.

Gratani, L; Taglioni, S; Crescente, MF (1992). The Accumulation of Lead in Agricultural Soil and Vegetation along a Highway. Chemosphere, 24: 941-949.

Grue, CE; Hoffman, DJ; Beyer, WN; Franson, LP (1986). Lead Concentrations and Reproductive Success in European Starlings Sturnus vulgaris, nesting within Highway Roadside Verges. Environmental Pollution Series A Ecological Biological, 42: 157-182.

Hafen, MR; Brinkmann, R (1996). Analysis of Lead in Soils Adjacent to an Interstate Highway in Tampa, Florida. Environmental Geochemistry and Health, 18(4): 171-179.

Herwitz, E (2001). Trees at Risk: Reclaiming an Urban Forest. Published by Chandler House Press. ISBN: 978-18862846. 208pp.

Ikenaka, Y; Nakayama, SMM; Muzandu, K; Choongo, K; Teraoka, H; Mizuno, N; Ishizuka, M (2010). Heavy Metal Contamination of Soil and Sediment in Zambia. African Journal of
Environmental Science and Technology, 4(11): 729-739.

Iqbal, MZ; Shazia, Y (2004). Differential Tolerance of Albizia lebbeck and Leucaena leucocephala at Toxic Levels of Lead and Cadmium. Polish Journal of Environmental Studies, 13(4): 439442.

Kalu, C; Anigbere, RF (2011). Social Benefits of Non-Timber Forest Products (NTFPS): An Assessment of Employment Generation from NTFPS Enterprises in Benin Metropolis, Edo State, Nigeria. Nigerian Journal of Agriculture, Food and Environment, 7(2): 30-35.

Konijnendijk, CC; Ricard, RM; Kenney, A; Randrup, TB (2006). Defining Urban Forestry - A Comparative Perspective of North America and Europe. Urban Forestry \& Urban Greening, 4(34): 93-103.

Lacatusu, R; Citu, G; Aston, J; Lungu, M; Lacatusu, AR (2009). Heavy Metals Soil Pollution State in Relation to Potential Future Mining Activities in Rosia Montana Area. Carpathian Journal of Earth Environmental Science, 4(2): 39-50.

Li, X; Poon, CS; Pui, SL (2001). Heavy Metal Contamination of Urban Soils and Street Dusts in Hong Kong. Applied Geochemistry, 16(11-12): 1361-1368.

Liu, B; Yong, Z; Li, Y; Khaldun, M; Aboul-Enein, HY (2015). A Comparative Study of the Contents of Cadmium and Chromium in Leaves of Seventeen Kinds of Road Greening Trees. World Journal of Analytical Chemistry, 3: 1-5.

Mabogunje, AL (1980). Development Process - A Spatial Perspective. Published by Hutchinson \& Co. Publishers Ltd. Pp. 234-244.

Maher, BA; Moore, C; Matzka, J (2008). Spatial Variation in Vehicle-Drived Metal Pollution Identified by Magnetic Elemental Analysis of Roadside Tree Leaves. Journal of Atmospheric Environment, 42: 364-373.

Nakayama, SMM; Ikenaka, Y; Hamada, K; Muzandu, K; Choongo, K; Teraoka, H; Mizuno, N; Ishizuka, M (2011). Metal and Metalloid Contamination in Roadside Soil and Wild Rats around a $\mathrm{Pb}-\mathrm{Zn}$ Mine in Kabwe, Zambia. Environmental Pollution, 159(1): 175-181. 
Pickett, STA; Cadenasso, ML; Grove, JM; Nilon, CH; Pouyat, RV; Zipperer, WC; Costanza, R (2001). Urban Ecological Systems: Linking Terrestrial Ecological, Physical, and Socioeconomic Components of Metropolitan Areas. Annual Review of Ecology and Systematics, 32: 127-157.

Trombulak, SC; Frissel, CA (2000). Review of Ecological Effects of Roads on Terrestrial and Aquatic Communities. Conservation Biology, 14(1): 18-30.

Turer, D; Maynard, JB (2003). Heavy Metal Contamination in Highway Soils. Comparison of Corpus Christi, Texas and Cincinnati, Ohio Shows Organic Matter is Key to Mobility. Clean Technology and Environmental Policy, 4: 235245.

Voegborlo, RB; Chirgawi, MB (2007). Heavy Metals Accumulation in Roadside Soil and Vegetation along a Major Highway in Libya. Journal of Science \& Technology, 27(2): 86-97.
Wheeler, GL; Rolfe, GL (1979). The Relationship between Daily Traffic Volume and the Distribution of Lead in Roadside Soil and Vegetation. Environmental Pollution, 18(4): 265274.

Yakupoglu, D; Guray, T; Sarica, DY; Kaya, Z (2008). Determination of Airborne Lead Contamination in Cichorium intybus L. in an Urban Environment. Turkish Journal of Botany, 32: 319-324.

Yaman, M; Dilgin, Y; Gucer, S (2000). Speciation of Lead in Soils and Relation with its Concentration in Fruits. Analytica Chimica Acta, 410: 119-125.

Zhang, F; Yan, X; Zeng, C; Zhang, M; Shrestha, S; Devkota, LP; Yao, T (2012). Influence of Traffic Activity on Heavy Metal Concentrations of Roadside Farmland Soil in Mountainous Areas. International Journal of Environmental Research and Public Health, 9(5): 1715-1731. 